\title{
Gaz ziemny w motoryzacji w walce ze smogiem
}

CNG - Compressed Natural Gas (sprężony gaz ziemny).

NGV - Natural Gas Vehicles (pojazdy napędzane gazem ziemnym).

LNG - Liqueified Natural Gas (skroplony gaz ziemny).

Nagle zaczęliśmy zwracać w Polsce uwagę na zanieczyszczenie powietrza. Mimo że środowisko naturalne jest degradowane ustawicznie i znane są możliwości ochrony powietrza oraz zasobów naturalnych ziemi, które wpisane zostały do zrównoważonego rozwoju w XXI wieku. Problemy zagrożeń środowiska naturalnego, które wynikają z użytkowania pojazdów są coraz dokładniej identyfikowane. Różnymi metodami próbuje się zmniejszyć szkodliwe odziaływanie pojazdów na środowisko. Wprowadza się nowe rozwiązania konstrukcyjne i zaostrza obowiązujące normy, ograniczające emisję substancji szkodliwych do atmosfery.

Zapomina się jednak o analizie negatywnych skutków dla środowiska naturalnego, jakie wynikają z braku wdrażania niektórych technologii i spychaniu na margines paliw, które za sprawą wielu czynników nie są stosowane. Przykładem takiego paliwa samochodowego w Polsce jest gaz ziemny. Jako paliwo silnikowe był używany już w XIX wieku. Pierwszy

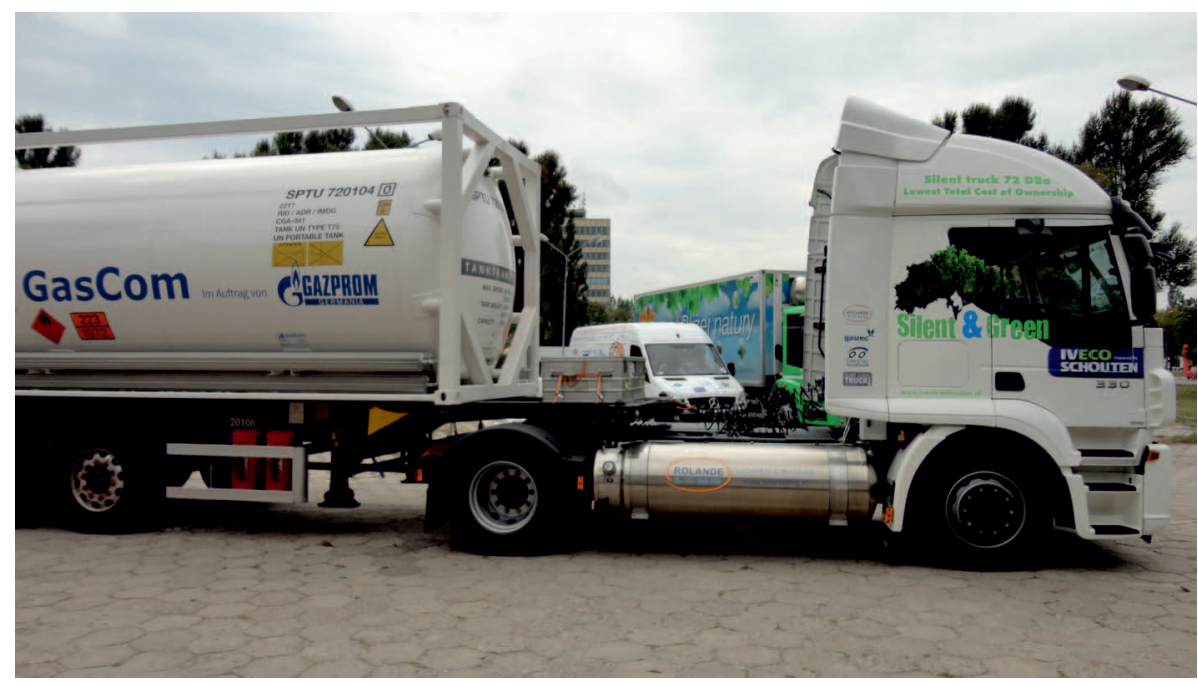

Fot. 1. Ciągnik siodłowy mogący tankować CNG lub LNG wraz z cysterną LNG w historii silnik spalający gaz skonstruowany zostały w 1860 roku przez Etienne'a Lenoira. Kolejny silnik gazowy, czterosuwowy, skonstruował August Otto w 1878 roku. Od tamtego czasu silniki gazowe przeszły wiele przeobrażeń, a technologia i technika w nich wykorzystywane zostały całkowicie opanowane.

Natomiast w Polsce szuka się ustawicznie rozwiązań nowych. Dlaczego nie sięga się po sprawdzone, które można wprowadzić, oszacować koszty i zysk oddychania czystym powietrzem? Niektórzy zastanawiają się nad pojazdami elektrycznymi, nie bacząc, czy linie przesyłowe wytrzymają zwiększony przesył. Czy prąd pozyskany zostanie w sposób ekologiczny, a może z węgla i gdzie zutylizowane zostaną zużyte akumulatory?

$\mathrm{Na}$ świecie i w Europie sprężony gaz ziemny wprowadza się systematycznie $\mathrm{w}$ trosce o stan środowiska naturalnego i dywersyfikację dostaw paliw silnikowych. Postęp cywilizacyjny spowodował taki przyrost środków transportu, że realna stała się obawa, iż wyczerpią się w niedalekiej przyszłości zasoby paliw ropopochodnych. CNG uznany został za pomost do paliw wodorowych, które mają stać się popularne w niedalekiej przyszłości. Dyrektoriat Generalny Energii i Transportu Unii Europejskiej wymienił trzy paliwa substytucyjne jeszcze przed rokiem 2000. Przedstawił optymalny scenariusz rozwoju rynku paliw dla środków transportu, który zakładał procentowy udział CNG na rok 2020 w wysokości $10 \%$ paliw samochodowych. Udział pozostałych paliw substytucyjnych w tym samym roku miał wynieść: 


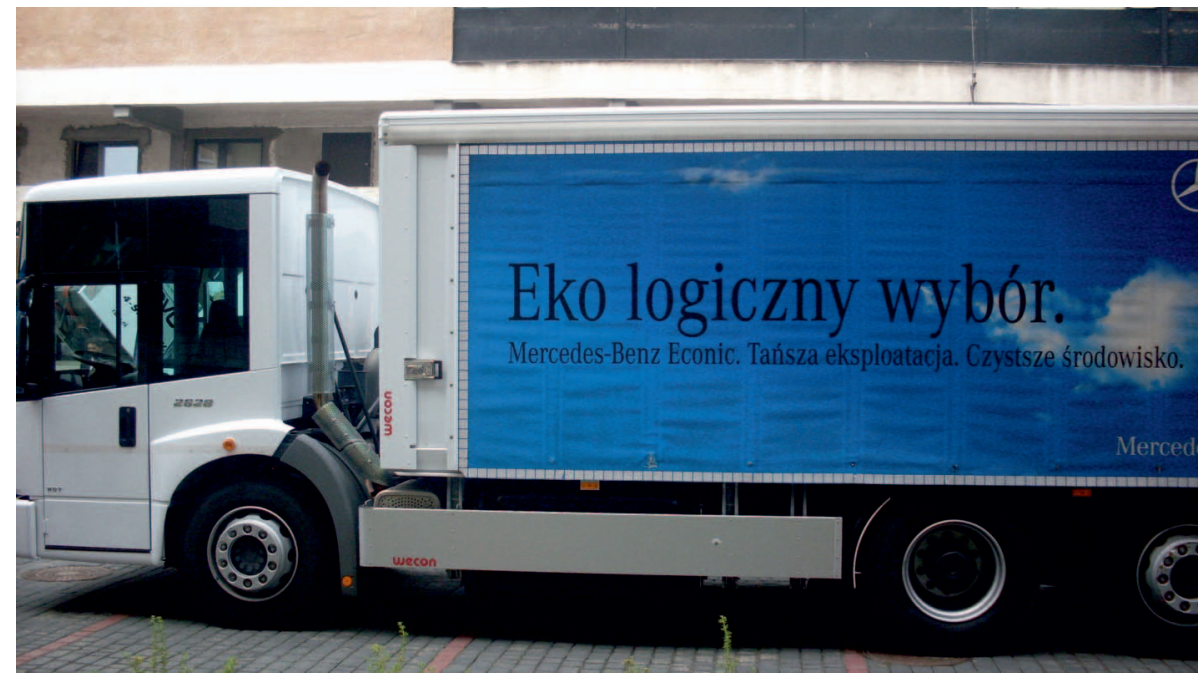

Fot. 2. Fabryczny samochód ciężarowy na $\mathrm{CNG}$ nienakładanie, wprowadzenie ulg podatkowych dla użytkowników NGV, zwrot podatku dochodowego, dotowanie inwestycji, obniżenie opłat z tytułu parkowania NGV w centrach miast, nakaz stosowania procentowego udziału paliw alternatywnych w firmach transportowych, dotacje do ceny zakupu NGV, obowiązek stosowania paliw alternatywnych w dużych aglomeracjach miejskich itp.

Wiele lat temu pracowałem na stacji tankowania sprężonym gazem ziemnym. Rozmawiałem wielokrotnie z obcokrajowcami posiadającymi samochód na to paliwo. Zawsze pytali, gdzie mogą zatankować CNG w Polsce. Nie rozumieli $8 \%$ dla biopaliw, a 5\% dla wodoru. Największy udział CNG $\mathrm{w}$ tej grupie paliw prognozowano na podstawie jego dużych zasobów naturalnych, wysokiego bezpieczeństwa użytkowania takich silników, ekologicznych zalet, całkowitego opanowania technologii, magazynowania, dystrybucji i użytkowania. W Polsce mamy własne zasoby gazu, ale tej polityki europejskiej nie realizujemy.

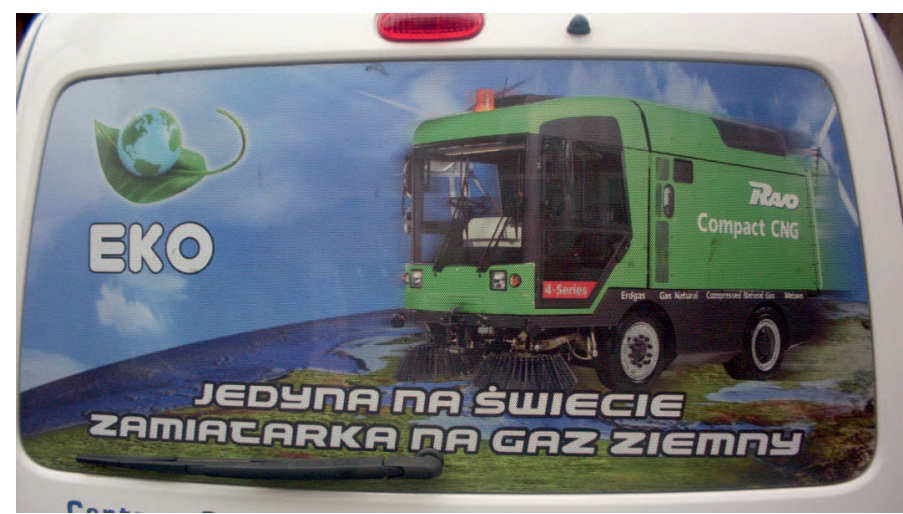

Fot. 3. Pojazd techniczny zasilany sprężonym gazem ziemnym

Prawie 40 producentów samochodów na całym świecie produkuje już ponad 150 modeli pojazdów zasilanych CNG. Seryjnie produkowane są nie tylko samochody zasilane gazem ziemnym, ale różne pojazdy, których silniki posiadają zamkniętą komorę spalania. Poza Polską eksploatowane są na tym paliwie: motorynki, motocykle, gokarty, kosiarki ogrodowe, promy, poduszkowce, statki wycieczkowe, lokomotywy, ratraki, pojazdy oczyszczania miasta i wiele innych. Firmy podjęły wyzwanie przyszłości, a ekonomia i troska o środowisko nakazały im inwestowanie w rozwój tego paliwa.

Polityka podatkowa wielu państw sprzyja początkom wprowadzania CNG na rynek paliw. Istnieją różne programy krajowe (dotychczas brak takich rozwiązań w Polsce), które wspierają to paliwo poprzez obniżenie akcyzy na CNG lub jej dlaczego przez całą Europę przejeżdżają na gazie ziemnym, a w Polsce zmuszeni są tankować benzynę.

Stojąc wielokrotnie za rurą wydechową takiego pojazdu w chwili uruchamiania silnika przez kierowcę, od razu mogłem wyczuć, że jest to paliwo ekologiczne. Patrząc na kolor rury wydechowej, która nie jest czarna nawet $w$ autobusach zasilanych CNG i brak obłoku sadzy miałem pewność, że paliwo to niesie ze sobą mniej negatywnych skutków dla środowiska naturalnego niż benzyna czy olej napędowy. Wszyscy sceptycy tego paliwa, których miałem przyjemność zaprosić na „randkę z rurą wydechową", wyrażali konsternację i zdziwienie, gdy stali za autobusem zasilanym CNG podczas uruchamiania silnika. Obecnie znowu o tym się nie pamięta. Mówi się głośno tylko o pojazdach elektrycznych.

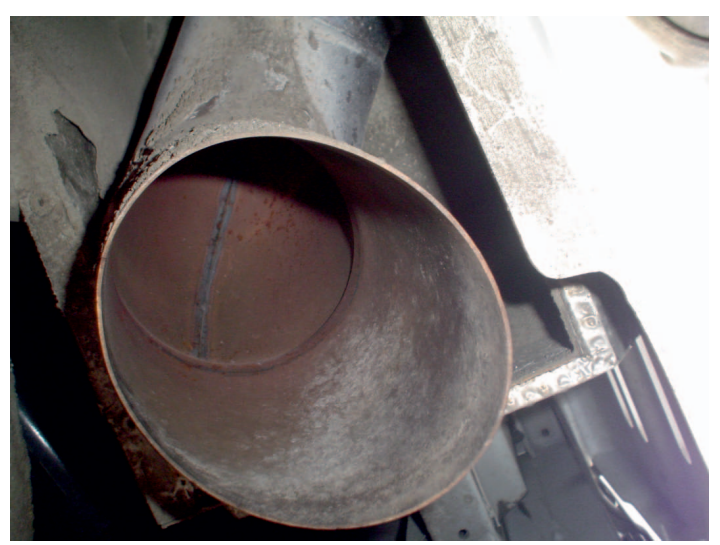

Fot. 4. Rura wydechowa autobusu zasilanego CNG

Na rentowność wprowadzenia gazu ziemnego jako paliwa samochodowego na szeroką skalę wpłynie tylko program rządowy. Na przykład w Niemczech z budżetu centralnego na budowę infrastruktury w roku 2004 wydano $200 \mathrm{mln}$ euro, a we Francji rząd wydał nakazy stosowania paliw alternatywnych dla przewoźników. 
W Polsce tego typu działania zapisano w Programie Zrównoważonego Rozwoju Miasta, który wynika z tezy Zrównoważonego Rozwoju Kraju przyjętego w listopadzie 1999 roku przez Komitet Ekonomiczny Rady Ministrów na lata 2000-2015 w sprawie finansowania rozwoju regionalnego opartego na współpracy samorządów i zainteresowanych resortów administracji. Jednak zapomniano o tym skoro rozważa się elektryfikację samochodów.

Przepisy promujące CNG obowiązują już w wielu miastach europejskich, a są podyktowane troską o środowisko naturalne, gdyż zastosowanie paliw alternatywnych przyczynia się do zmniejszenia hałasu oraz zadymienia, redukcji emisji szkodliwych spalin itp. Pojazdy zasilane CNG nie emitują cząstek sadzy. Brak efektu dymienia wpływa nie tylko na wyraźną różnicę powietrza w okolicy pojazdu, ale ma dodatkowy efekt w postaci rzadszego malowania elewacji zewnętrznej budynków. Z tego powodu pojazdy takie nie mają tylu ograniczeń ruchu w centrach miast. Rzadsze malowanie oznacza wprowadzenie mniejszej ilości substancji szkodliwych do atmosfery. Tak samo sporadycznie remontowane są hale, również podziemne, w których garażowane są takie pojazdy.

Transport gazu ziemnego rurociągami do stacji tankowania oznacza jednocześnie odciążenie dróg z transportu ciężkiego. Rzadziej na naszych drogach spotkamy cysterny dowożące paliwo do stacji tankowania. Później też będziemy kłaść kolejną warstwę asfaltu na drodze, gdyż odciążona, będzie rzadziej remontowana. Parujący, ciepły asfalt emituje przecież znaczne ilości substancji szkodliwych. Skład CNG i brak w nim substancji kancerogennych wydłuża żywotność silnika. Poddany będzie on zatem powtórnemu przerobowi później niż silnik benzynowy.

Troska o klimat widoczna jest głównie w dużych aglomeracjach miejskich, gdyż to tam pojawiają się alerty smogowe. Polityka europejska sięga szeroko w tym zakresie, gdyż przedstawia szereg projektów łączących miasta i kraje wspólnoty na paliwach niskoemisyjnych. Mowa tu nie tylko o drodze lądowej, ale o żegludze śródlądowej i transporcie morskim.

Dyrektywa w sprawie rozmieszczenia infrastruktury paliw alternatywnych wymienia punkty tankowania LNG, które należy zbudować we wszystkich portach morskich i śródlądowych. Odstępy pomiędzy stacjami tankowania LNG i CNG wzdłuż autostrad mają zapewnić swobodne przejazdy tym pojazdom po Transeuropejskiej Sieci Transportowej (TEN-T). Kolejnymi paliwami, które umożliwią zastąpienie energii z paliw ropopochodnych wymienionymi w dokumencie z 24 stycznia 2013 roku są: wodór, biopaliwa i energia elektryczna.

Aktualnie w Polsce są produkowane pojazdy zasilane CNG. Przez wiele lat montowały je następujące firmy: Polskie Autobusy, Volvo, Solaris, Solbus, Fiat i Volkswagen. Kilku autoryzowanych dealerów w naszym kraju oferuje takie pojazdy, mimo małego zainteresowania spowodowanego brakiem sieci stacji. W Europie zatankowanie pojazdu paliwem alternatywnym nie stanowi problemu. Należy umożliwić Polakom zakup takich pojazdów fabrycznie nowych. Wesprzeć to polityką antysmogową, co od zaraz zacznie przynosić efekty w poprawie jakości powietrza, którym oddychamy. Zmniejszy się emisja substancji szkodliwych z rur wydechowych i metanu z wysypisk komunalnych, jeżeli go zagospodarujemy jako paliwo silnikowe. Efekt skali, a nie pojedynczego użytkownika będzie odczuwalny.

Co, jeśli wprowadzimy auta elektryczne zamiast zasilanych CNG? Na pewno będziemy czekać na efekt znacznie dłużej. Ile mamy rodzajów pojazdów elektrycznych dostępnych w salonach od ręki? Ile przemysł dostarczy ich rocznie do Polski? Na pewno o kilka tysięcy sztuk rocznie mniej, a więc możemy o natychmiastowym efekcie poprawy powietrza zapomnieć. Należy zatem wprowadzać przede wszystkim te paliwa które gwarantują zastąpienie dużej liczby pojazdów zasilanych paliwami tradycyjnymi. Pojazdy elektryczne mogą się stać taką alternatywą, ale za kilka lat. Dlatego trzeba w nie inwestować. Nie można jednak twierdzić, że elektryfikacja pojazdów zwalczy smog szybko.

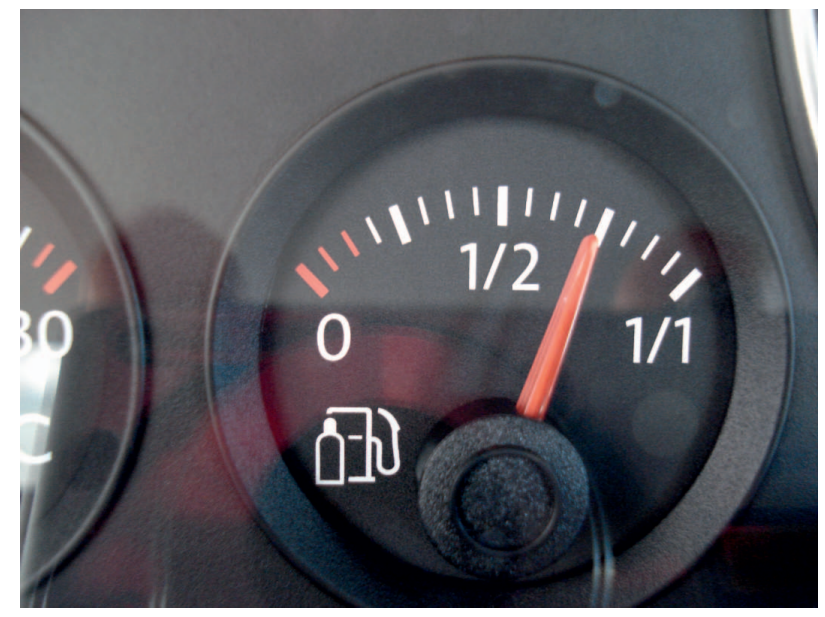

Fot. 5. Wyświetlacz fabryczny NGV pokazujący przemiennie poziom CNG lub benzyny

Swoją drogą ciekawe, czy dzienna równowartość nieskasowanych biletów w MZA Warszawa, gdy jest smog i jeździ się bezpłatnie komunikacją, nie generuje straty umożliwiającej zakup jednego kolejnego autobusu na CNG lub LNG dla miasta. Może ktoś może to policzyć.

Barierą rozwoju pojazdów CNG w naszym kraju jest ich procedura rejestracyjna. Urzędnicy i diagności wymagają odmiennych dokumentów. Luki w przepisach powodują, że właściciel dwóch takich samych samochodów musi spełnić odmienne wymagania dla każdego z nich w celu dopuszczenia ich do ruchu w Polsce. Należy to jak najszybciej zmienić, gdyż nawet kilkuletni samochód NGV, sprowadzony do kraju 
emituje mniej zanieczyszczeń, niż podobny pojazd zasilany benzyną czy olejem napędowym. Nawet pojazdy wyposażone $\mathrm{w}$ instalację gazową przez producenta pojazdu przed pierwszą rejestracją oznaczone w symbolu modelu, CNG, Bipower, Monovalent Plus itp. $\mathrm{w}$ dowodzie rejestracyjnym w rubryce adnotacje urzędowe uzyskują wpisy: ,gaz” lub ,pojazd przystosowany do zasilania gazem". Takie oznaczenie modelu w świadectwie homologacji powinno zapewnić, że rubryka ta w dowodzie rejestracyjnym pozostanie pusta. Gdyż służy do wpisywania istotnych zmian w pojeździe które zostały w nim dokonane poza producentem.

Przed uzyskaniem polskiego dowodu rejestracyjnego należy poddać pojazd dodatkowym badaniom technicznym instalacji gazowej, wraz z badaniem zbiorników gazu ziemnego w pojeździe. Mimo że Europejczyk w Polsce i poza nią może tym samochodem jeździć bez tych wymagań po drogach całej wspólnoty.

Zaniedbania promocji ekologicznych paliw w Polsce, a w szczególności CNG coraz bardziej popularnego na świecie i w Europie, brak kompleksowych regulacji prawnych z tego zakresu, niedoinformowanie społeczeństwa, a także brak długoterminowego programu rządowego promującego to i inne paliwa ekologiczne, zgodnego z prognozami instytucji unijnych spowodowały, że mamy teraz problem w postaci smogu. $\mathrm{Na}$ nasze życzenie pojazdy dwupaliwowe, którymi przejeżdżają przez nasz kraj Europejczycy emitują do atmosfery produkty spalania paliw ropopochodnych, a nie gazu ziemnego, gdyż nie mogą go zatankować w Polsce. Każdy posiadacz samochodu wyposażonego w dwa układy paliwowe wybiera paliwo, które jest tańsze - CNG jest tańszy od benzyny. Jeśli nie możemy go zatankować w Polsce to będziemy jeździć na droższej benzynie. Unia Europejska celowo wpływa na zmniejszenie ceny $\mathrm{CNG}$ w celu rozpowszechnienia tego paliwa.

Mimo że cena CNG jest niższa od benzyny, to brak jej stabilności w dalszej perspektywie przy braku planu budowy sieci stacji tankowania gazu ziemnego z gwarancjami rządowymi powodują, że to ekologiczne, zwane „błękitnym paliwem”, omija naszą gospodarkę. Tylko szerokie zainteresowanie problematyką zagrożeń naturalnego środowiska, wynikających z użytkowania pojazdów może doprowadzić do zmiany tego stanu rzeczy w Polsce. Wzorem państw europejskich powinniśmy zadbać o stworzenie sieci stacji tego paliwa na terenie całego kraju. Umożliwić uruchamianie garażowego tankowania pojazdów w domkach jednorodzinnych przyłączonych do miejskiej sieci gazowej. Uruchomić krajową informację o wydarzeniach związanych z CNG, a nie podchodzić do zagadnienia, jak do problemu występującego okazjonalnie.

W Warszawie jeździ 35 autobusów zasilanych LNG. Dlaczego nie zwiększyć znacząco tej liczy? Jeżdżą śmieciarki zasilane CNG. Czemu nie wymienić starych pojazdów z silnikami diesla na kilkanaście kolejnych śmieciarek CNG? Kto w miastach, a kto w całym kraju decyduje o ciągłości polityki transportowej? Ważna jest konsekwencja. Należy popularyzować CNG i LNG wraz z biometanem, który można pozyskać ze stert odpadów komunalnych, wprowadzać znane i sprawdzone rozwiązania i równolegle nowe trendy jak pojazdy elektryczne.

Jako właściciel samochodu zainteresowany jestem ograniczeniem kosztów eksploatacji samochodu oraz wszystkimi formami propagowania na polskim rynku paliwa silnikowego w postaci CNG. Wierzę głęboko, że jest to droga ku poprawie środowiska naturalnego, w którym żyjemy i inwestycja w przyszłość, dzięki której zapomnimy o smogu w polskich miastach.

W artykule wykorzystano zdjęcia pojazdów na gaz ziemny wykonane podczas pokazów promujących ekologiczny transport.

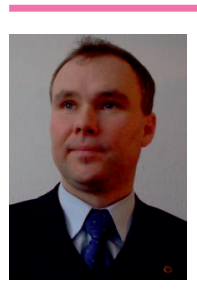

Gerard BARTŁOMIEJCZYK

Rzeczoznawca Stowarzyszenia Naukowo-Technicznego Inżynierów i Techników Przemysłu Naftowego i Gazowniczego w zakresie gazownictwa, specjalność: technika i technologia wykorzystania CNG jako paliwa do napędu pojazdów mechanicznych.

E-mail: gerard.bartlomiejczyk@op.pl 